\title{
Diacylglycerol Kinase Zeta
}

National Cancer Institute

\section{Source}

National Cancer Institute. Diacylglycerol Kinase Zeta. NCI Thesaurus. Code C150102.

Diacylglycerol kinase zeta (1117 aa, $\sim 124 \mathrm{kDa}$ ) is encoded by the human DGKZ gene.

This protein is involved in the phosphorylation of the second messenger molecule diacylglycerol. 